\title{
Sustained municipal waste management models in Russian megapolicies through utilizing waste- to-energy technologies
}

\author{
Arsalan Asadpoori ${ }^{1 *}$, Candido Ankomah ${ }^{1}$, Ardalan Asadpoori ${ }^{2}$, Oleg Derevianko ${ }^{1}$, and \\ Evgenii Shaburov ${ }^{1}$ \\ ${ }^{1}$ Peter the Great St.Petersburg Polytechnic University, Polytechnicheskaya, 29, St. Petersburg, 195251, \\ Russia \\ ${ }^{2}$ Department of Mechanical engineering, Azad University of Khomeini Shahr, 8418148499, Isfahan, \\ Iran
}

\begin{abstract}
St. Petersburg, as the second most important Russian city in Russia is facing with waste related problems which requires taking immediate actions. The excessive diurnal volume of municipal waste generation and insufficient waste management system ring the bells to warn the decision makers. Focusing on problems, insufficiencies and opportunities of the waste management system, the paper goes through the evaluation of details of the dominant situation in St. Petersburg and two models are introduced to improve the system. At the end, an estimation of biofuel, heat and electricity generation will be provided for four incineration facility installments with design capacity of each 315,000 tons of waste per day. It will be shown that the contributing share of bioconversion processes is significant and an acceptable portion of $8 \%$ of annual electricity consumption can be supplied via those processes as well as production of 477 million liters of ethanol.
\end{abstract}

\section{Introduction}

St. Petersburg (SPB) lies alongside the coastal border with Gulf of Finland and it is surrounded by wide green area which can unlimitedly spread the possible pollutants to the adjacent regions and countries. Despite the applied measurements to protect the environment, there is a concerning fact that some insufficiencies require amendment [1-6]. Beside the power plants, industrial sector and agriculture, landfills are known responsible for their polluting emissions in the air [7-11]. Emissions from landfills such as methane and $\mathrm{CO}_{2}$ are pernicious as they are potent to threaten the urban environmental system. Greenhouse gases are made up of such elements and they are blamed for global warming phenomena [12-14].

* Corresponding author: arsalan.asadpoori@gmail.com 


\section{Methods}

Supporting and governing regulations as well as clean tech start-up investments seem essential to facilitate such developments in SPB. In Finland and Estonia, as two neighboring countries, Municipal Waste (MW) is being utilized for useful fuels production and electricity generation.

In Fig. 1, it is shown that Finland has kept its waste treatment rate almost without any change but acceptable within a decade by 2015 . Almost 50 percent of MW is burnt in 7 incineration and co-incineration facilities in Finland [15]. Estonia already reached 25\% of renewable energy sources in gross ultimate energy consumption targeted by the National Renewable Energy Action Plan [16]. In 2015, almost 300 thousand tons of MW was utilized to generate $15,869 \mathrm{GWh}$ electricity and $8,608 \mathrm{GWh}$ heat $[17,18]$. Within the same period, Russia had stuck to the bottom of the graph fluctuating around $40 \mathrm{Kg}$ per capita.

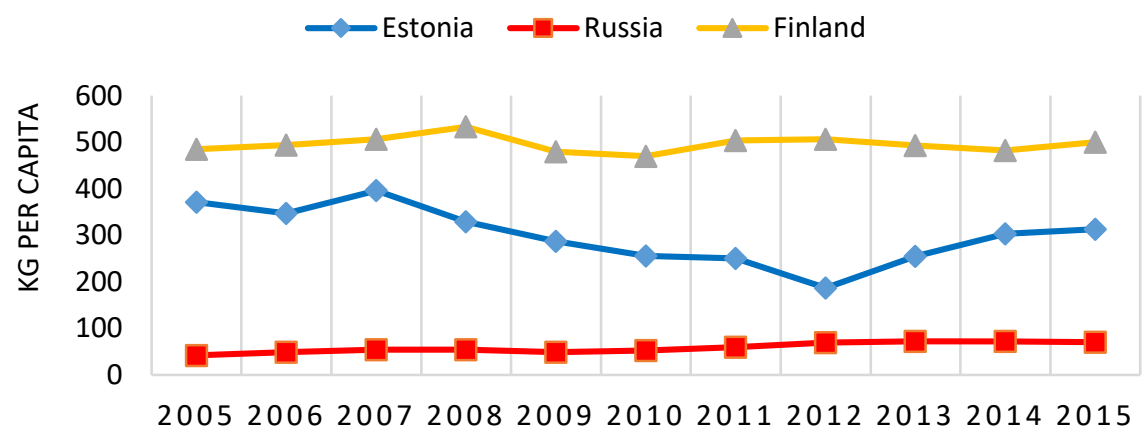

YEAR

Fig. 1. Waste treatment trend

As shown in Fig.2, landfilling in both Finland and Estonia look promising as they have experienced reductions more than $70 \%$ and $81 \%$, respectively while the landfilling trend for Russia soared for almost 100 percent by 2015.

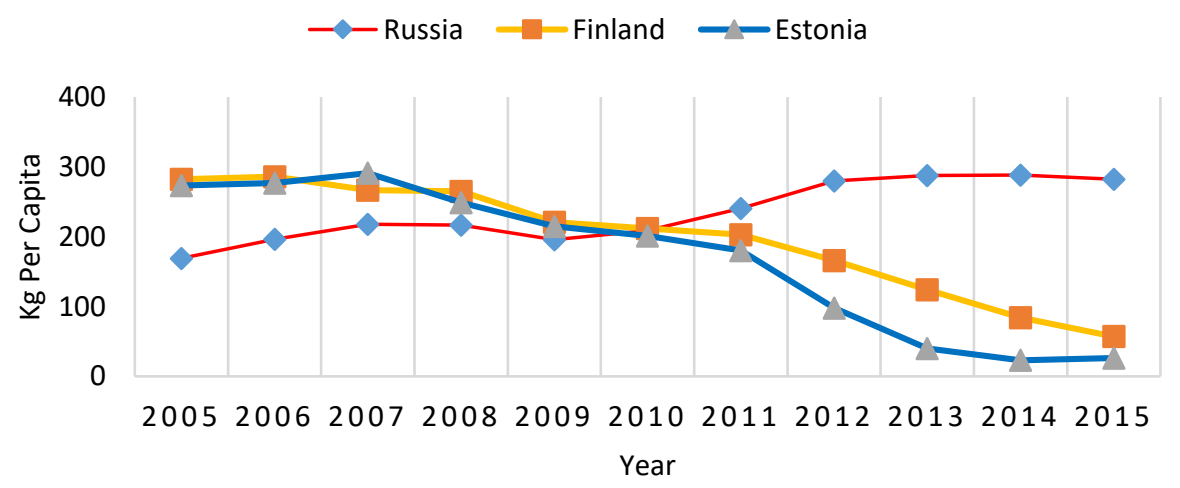

Fig. 2.: Landfilling trend

It is shown in Fig. 3 that the rate of waste generation has been increased for almost $100 \%$ during the same decade by reaching almost 5,500 million tons per year while the whole 
population remained well above $143,400,000$ people. One can consider lack of public consumption paradigms as a reason for such trend.

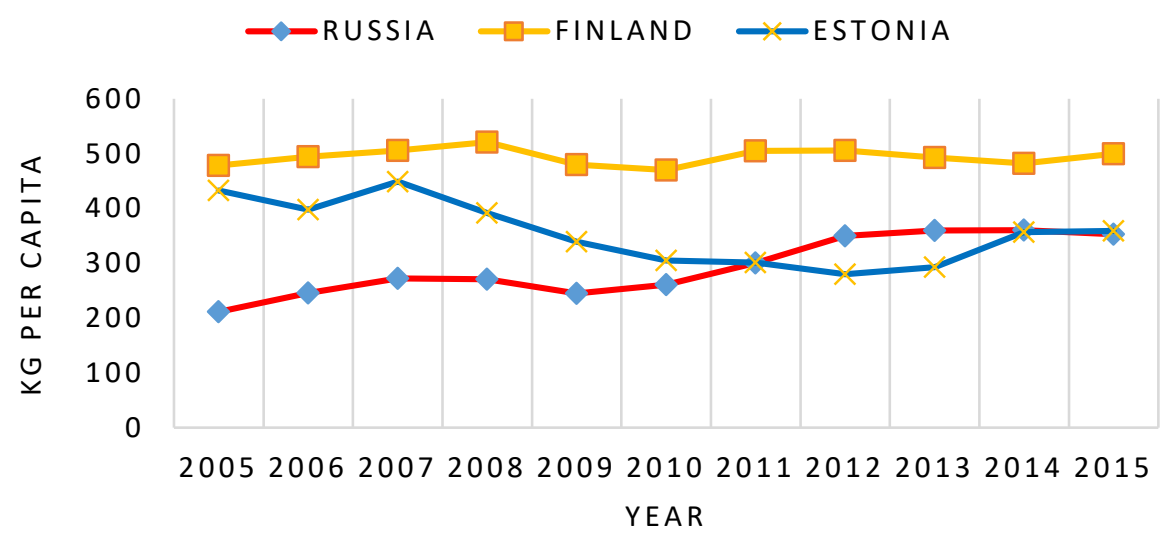

Fig. 2. Waste generation trend

The total amount of MW hauled from the SPB is 1,800 thousand tons roughly based on the administration disposal report in 2015. Only 20 percent of MW is recycled. Currently, MW is hauled to a couple of waste processing plants, MPBO-1 and MPBO-2. MPBO-1 ages more than 35 years. The first line of MPBO-2 began to operate in 1996. MPBO-2, as the second line, implements aerobic composting of organic portion of waste.

\section{Results}

Two landfills of PTO-1 and PTO-3 accommodate $80 \%$ of the MW. Almost 354 hectares of land in the city is occupied for PTO-3 and decommissioned landfills excluding the unorganized and illegal landfills. In Table 1, companies involved in the waste management system in the SPB are listed.

Table 1. Current waste treatment facilities in SPB [19]

\begin{tabular}{|c|c|}
\hline Company & Activity \\
\hline $\begin{array}{l}\text { Leningrad Regional } \text { Environmental } \\
\text { Company }\end{array}$ & Hazardous waste separation \\
\hline Ekoprom-Holding & Collection, transport and disposal of oily waste \\
\hline $\begin{array}{l}\text { St. Petersburg State Unitary Enterprise } \\
\text { Plan (MPBO-1\&2) }\end{array}$ & $\begin{array}{l}\text { Wastes removal and neutralization } \\
\text { Aerobic composting of organic waste }\end{array}$ \\
\hline Business Petersburg & Tire recycling \\
\hline UNEP & $\begin{array}{l}\text { Disposal of fluorescent lamps and mercury- } \\
\text { containing waste }\end{array}$ \\
\hline Nightman in St. Petersburg & $\begin{array}{l}\text { Collection and disposal of waste of 3-5 hazard } \\
\text { classes }\end{array}$ \\
\hline
\end{tabular}

Dwellers in the city dispose mixed waste into bins. Collecting companies only collect such waste, transport and dispose it. Practically, householders are not involved in waste separation. Tariff Committee of the SPB sets new fees for waste collection and disposal every year. Based on current regulations, citizens have to separate waste and deliver the recyclable materials such as glass, the PCB and electronic types to some companies. Delivering $1 \mathrm{~kg}$ of 
paper to the collection stations, 10 Rubles (0.17 US Dollars based on current exchange rate) will be paid back to the courier as the financial encouragement. A glass bottle brings back even much lower money than paper i.e. $0.0087 \$$. Without any separation, a monthly fee of 3.71 rubles per square meter of a flat was charged for waste collection, transportation and separation. As an instance, it costs 148.4 Rubles in a month for a $40 \mathrm{~m}^{2}$ flat (common area for newly built flats). Regarding time and fuel consumption to hand in recyclable materials, it is ineffective to do waste separation at homes and deliver to the collecting stations [20].

Long waste transportation distance leads to high fuel consumption and transportation cost; For example, Novyj Svet, a landfill in Gatchina district, is located more than $45 \mathrm{Km}$ away from the center of SPB. Through a "recycling experiment", two different types of containers were placed at streets of the city in 2002. The experiment terminated in 2009 without reaching the aims as people were not informed how to work with this mechanism [21].

Some environmentally-friendly solutions such as adopting new technologies to capture the emissions for non-electric energy applications and the utilization of WtE facilities are suitable for this city [22-30]. On one side, environment protection regulations and reduction strategies such as governmental steered incentives to entice companies to invest on contribution and on the other side, people's involvement can involve both public and private sector in this upheaval [31-33].

\section{Case study: St. Petersburg (SPB), Russia}

The cultural difference between both models shows up at the beginning of the first scenario where public awareness is targeted actively. Hazardous types of waste can be processed in incinerators [34,35]. Recyclable and combustible materials can be utilized for recycling purposes. The outputs can be used as raw materials for new products.

Through both scenarios, incineration will be adopted and financial and quantitative aspects of electricity and heat generation will be explained in details.

\section{Scenario one (Source separation)}

Direct transportation of waste (separated) from houses to the treatment facilities is aimed. Household waste contains mixed valuable materials. Separation of dry materials can be done easily. Inhabitants are asked to segregate organic waste and throw it in a specific bin. Four different bins for separating plastic, glass, paper and food leftovers are considered. To prevent producing non-recyclable materials for bags, the containers are proposed to be made up of paper for glass, plastic and paper, except for food leftovers. Householders are not obliged to proceed source separation but in such cases, dwellers will be charged a specific tariff for waste separation which are considerable.

\section{Features of first scenario}

Waste landfilling will decrease as well as landfill occupation. As an advantage, recycling the reusable materials helps decreasing the raw material consumption. Fertilizers and thermally valuable products are obtainable which can be utilized instead of fossil fuels. Consequently, an increase in contributing share of biofuels for electricity and heat generation is anticipated as well as a reduction in environmental pollution.

Furthermore, by locating WtE facilities in specially selected locations, transportation length is shortened. Consequently, a significant reduction in transportation cost and imminent pollution leakage within transportation operation is expectable as well as maintenance cost of trucks and drivers' fatigue.

\section{Challenges in first model}

Lack of public awareness is a noticeable challenge through this model. TV programs, Educational symposiums, public events and encouraging programs seem essential. As an instance, scheduling related instructions at schools and universities is an appropriate way to 
familiarize the society especially young generation with environmental issues. Such activities form new behavioral paradigms in people.

\section{Scenario two}

Specific units perform waste separation instead of householders. Waste is hauled to waste separation facilities prior to delivery to the waste treatment facilities. Thus, people will pay a considerable tax for waste separation activities in this model. Such payment should be defined based on waste separation operation including labor and equipment costs. This centralized separation costs more but provides higher efficiency than source separation as the waste segregation will be done via specific equipment. Alike to the first scenario, shorter transportation lengths are considered simultaneously.

Culturalization is just directed toward consuming and purchasing efficiently. Efficient purchase results in less raw material consumption for commodity production.

Household waste is hauled by specific trucks to waste separation facilities. Then, it is well managed to carry related materials to the most suitable treatment centers. As an instance, organic compounds can be sent to composting centers.

\section{Features of second scenario}

People will be familiar with the crucial issue of waste management via undergoing extra fees for waste separation as well as encouraging alternatives. More efficient waste separation is the other feature although it is not cost effective comparing with first scenario.

\section{Challenges for second scenario}

More land occupation and higher investment cost are considered as the main challenges of this scenario. Investment cost of waste separation facilities can be paid off through applying appropriate taxes. A balance between taxes and state incentives assigning to collection and separation companies leads to a profitable operation for all the parties.

\section{Estimation of biofuel production}

Maximum volume of 477,000,000 liters per year can be predicted for ethanol production in SPB. Also, by using only $30 \%$ of annual potent waste for biodiesel production, 523,800 liters of biodiesel can be generated through transesterification process.

\section{Quantitative analysis of incineration technology in both scenarios}

\section{Estimation of heat and electricity generation}

Both assumptions and statistics are used to estimate viable amounts of electricity and heat generating through utilization of incinerators. Therefore, it has been tried to apply values and assumptions close to the formerly implemented projects in Europe and the neighboring countries. In order to find out possible obtainable amount of electricity and heat, relative portions of useable materials in municipal waste are presented in Table 2. These values are calculated by multiplying annual volume of each type of municipal waste by its relative portion.

Table 2. Annual portion of common types of waste in SPB

\begin{tabular}{|l|c|c|}
\hline \multicolumn{1}{|c|}{ Type of waste } & Relative portion\% & Annual amount (ton) \\
\hline Organic waste & 27.4 & 493200 \\
\hline Paper and cardboard & 21.5 & 387000 \\
\hline Glass & 8.9 & 160200 \\
\hline Textiles, leather, rubber & 4.3 & 77400 \\
\hline
\end{tabular}

Dividing the annual values obtained in Table 4 by 365 (days of operation in a year), daily portions will be calculated. Accordingly, the roughly required design capacity is obtainable for waste treatment facilities. It is notable that volume of waste and its composition vary from one region to another and even within each season. Therefore, it is important to consider 
almost $1.5 \%$ annual growth in waste volume while calculating design capacity of waste treatment facilities.

Maximum volume of $70 \%$ of the annual waste are assumed to be used in incinerators. Thus, annual applicable volume of waste and its diurnal volume in incinerators are:

$Y=N \% \cdot($ Total volume of waste generated annually $)=$ Annual volume of waste applicable for incineration [per year] (1)

which means:

$Y=70 \% * 1,800,000=1,260,000\left[\right.$ tons. year ${ }^{-1}$ ]

And the daily volume as:

It means:

$$
P=\frac{Y}{365}
$$

$$
P=1,260,000 / 365=3452.05 \text { [tons. day }{ }^{-1} \text { ] }
$$

Following empirical data from previously done works, the calorific heat of a ton of municipal waste is almost 10 GJ. Maximum $28 \%$ electric efficiency can be anticipated for an incinerator and the rest of energy can be used as heat for local heating systems. In cogeneration operating mode, the efficiency can be at least $80 \%$ according to the lower heating value of waste. Therefore, maximum amount of $2.8 \mathrm{MWh}$ energy will be obtained from waste in an incinerator. For the calculation, the best operating mode is considered as $80 \%$ efficiency, including $28 \%$ electrical efficiency and 52\% thermal efficiency [36-38].

Therefore, it is calculated below the total electrical energy obtainable to supply urban area:

$$
E=P \cdot 2.8 \mathrm{MWh} \cdot 28 \%=\mathrm{MWe} \text { daily generated electricity }
$$

And the total heat energy which can be generated and supplied to urban heating system is

$$
H=P \cdot 2.8 \mathrm{MWh} 52 \%=\mathrm{MWh} \text { daily generated heat }
$$

which means:

$$
E=2706.407\left[\mathrm{MWe} \cdot \mathrm{day}^{-1}\right] \text { and } H=5026.184\left[\mathrm{MWh} \cdot \mathrm{day}^{-1}\right]
$$

The annual electricity consumption is 12.5 billion KWh in SPB. Incinerators can generate electricity annually for almost $8 \%$ through utilizing municipal waste. Considering annual electricity consumption of $300 \mathrm{Kwh}$ for a flat, the generated electricity through municipal waste can supply almost $3,300,000$ houses daily. By increasing the efficiency from $28 \%$ to $80 \%$ through cogeneration operating mode [39-42], the significant contribution of waste in heat and electricity generation should not be ignored. The annual average heat consumption for $1 \mathrm{~m}^{3}$ in SPB is estimated to be $290.5 \mathrm{KW} \cdot$ year $^{-1}$ [43] which accounts for $0.79 \mathrm{KW} \cdot \mathrm{m}^{-}$ ${ }^{2}$. day $^{-1}$. Considering $40 \mathrm{~m}^{2}$ as the average area of flats and assuming annual production of 1,834,557.16 MWh heat through waste, 158,000 flats can be heated annually.

\section{Economic analysis of installing incinerators in SPB}

Based on the proposed annual utilization of $70 \%$ or 1,260 thousand tons of municipal waste for energy generation in incinerators, 4 incineration plants, each with design capacity of 315,000 tons of waste per year are proposed. Accordingly, the investment cost of one incineration plant will be calculated below, briefly. Also, labor, emission and maintenance costs will be considered as well as revenues. Investment cost is only included in the net cost for the first year of operation while the other costs should be calculated for each of the following years based on inflation or other financial related factors. The inflation rate is extracted from the statistics of the central bank of Russian Federation.

The investment cost in million Rubles for an incineration plant is estimated using the empirical formula [44]:

$$
I=2.3507 \cdot C^{0.7753}
$$


where $\mathrm{I}$ is the installment cost in million dollars and $C$ is the plant capacity (103 metric tons of waste per year). Considering 56 as the exchange rate of dollar to ruble, the investment cost for an incineration plant with a capacity of 315,000 tons of waste per year is:

$$
I=2.3507 \cdot(315)^{0.7752}=11,384.8 \text { Million Rubles }
$$
follow:

The net cost of such plant includes investment cost and other minor costs introduced as

MW Plant cost $=$ Investment cost + Maintenance cost + operational cost

Annual maintenance cost is estimated as $3 \%$ of the total annual investment cost [44] which means

$$
\text { 3\% } 11,384.8=341.544 \text { Million Rubles }
$$

To shorten the process of calculation, only the final values are provided here for other parameters such as revenues, wastages and maintenance in Tables 3 and 4.

\begin{tabular}{|c|c|c|c|}
\hline Energy & $\begin{array}{l}\text { Selling price of energy } \\
\left.\left.\text { [Ruble } \cdot \mathrm{kWh}^{-1}\right]\right]\end{array}$ & 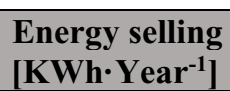 & $\begin{array}{c}\text { Revenues } \\
{\left[\text { Ruble· Year }{ }^{-1}\right]}\end{array}$ \\
\hline Electricity & 2.88 & $246,960,000$ & $711,244,800$ \\
\hline Heat & 1.96 & $458,640,000$ & $898,934,400$ \\
\hline $\begin{array}{l}\text { Waste } \\
\text { disposal }\end{array}$ & $218,358,000$ & & \\
\hline $\begin{array}{l}\text { Total } \\
\text { revenue }\end{array}$ & $1,828,537,200$ & & \\
\hline
\end{tabular}

Table 3. Revenues for an incineration plant [45]

Table 4. Costs for an incineration plant

\begin{tabular}{|c|c|}
\cline { 2 - 2 } \multicolumn{1}{c|}{} & Cost Per year[Ruble] \\
\hline Investment & $11,384,800,000$ \\
\hline Maintenance & $341,544,000$ \\
\hline Emission [46] & $123,895.296$ \\
\hline Labor & $24,360,000$ \\
\hline Net cost & $11,750,827,900$ \\
\hline
\end{tabular}

Considering $4.1 \%$ as the inflation rate for the first year, only for the first year, net cost includes investment cost, and it is excluded for the next following years. As the results of calculations, the entire investment cost will be covered fully after 10.72 years.

\section{Conclusion}

Through both presented models for waste management in St. Petersburg, it was observed that a huge precious volume of thermal energy from waste is being disposed in SPB every day. Using $70 \%$ of the generated waste, incineration technology represented supplement of 158,000 flats with heat energy and coverage of $8 \%$ of annual electricity consumption for almost 3,300,000 houses. Combining utilization of other technologies such as composting, anaerobic digestion, and gasification technology are also applicable which leads to higher energy generation efficiency. Assuming locating WtE facilities nearer to the city center, a tangible reduction is highly expected in transportation cost. Paid back time was obtained as 10.7 years. It will be important for money investors to assess the life cycle of the facilities. 


\section{References}

1. 1 N. Arefiev, V. Garmanov, V. Bogdanov, Y. Ryabov, V. Terleev, and V. Badenko, Procedia Eng. 17, 26-31 (2015).

2. 2 M. Bukova, A. Bondal, O. Skvortsova, O. Nikonova, A. Kholodiakov, I. Guseva, T. Makarova, and W. Mirschel, MATEC Web Conf. 73, 03002 (2016).

3. 3 M.G. Ryzhakova, V.I. Maslikov, A.N. Chusov, and V.V Korablev, Appl. Mech. Mater. 675-677, 761 (2014).

4. 4 N. Braila, A. Kirilkina, and S. Barinov, IOP Conf. Ser. Earth Environ. Sci. 90, 012219 (2017).

5. 5 E.D. Malevskaia-Malevich and D.S. Demidenko, in IOP Conf. Ser. Earth Environ. Sci. 601 (2017).

6. 6 V.M. Borovkov, L. V Zysin, and V. V Sergeev, Izv. Akad. Nauk. Energ. 13, 17 (2002).

7. 7 M. El-Fadel and M. Massoud, Environ. Technol. (United Kingdom) 21, 965 (2000).

8. 8 A.N. Chusov, V.I. Maslikov, D. V Molodtsov, V. V Zhazhkov, and O.A. Riabuokhin, Mag. Civ. Eng. 58, 44 (2015).

9. 9 V. Maslikov, A. Chusov, V. Zhazhkov, and O. Vasilyeva, Adv. Intell. Syst. Comput. 692, 908 (2018).

10. 10 T. Orlova, A. Melnichuk, K. Klimenko, V. Vitvitskaya, V. Popovych, I. Dunaieva, V. Terleev, A. Nikonorov, I. Togo, Y. Volkova, W. Mirschel, and V. Garmanov, IOP Conf. Ser. Earth Environ. Sci. 90, 012110 (2017).

11. 11 V. Maslikov, E. Negulyaeva, A. Cheremisin, A. Chusov, D. Molodtsov, and A. Stroganov, Solid State Phenom. 871, 199 (2016).

12. 12 A. Dai, Wiley Interdiscip. Rev. Clim. Chang. 2, 45 (2011).

13. 13 Y. Hirabayashi, R. Mahendran, S. Koirala, L. Konoshima, D. Yamazaki, S. Watanabe, H. Kim, and S. Kanae, Nat. Clim. Chang. 3, 816 (2013).

14. 14 N.I. Didenko, D.F. Skripnuk, and O. V Mirolyubova, IOP Conf. Ser. Earth Environ. Sci. (2017). DOI: 10.1109/MLSD.2017.8109611

15. 15 Waste statistics, Environment and Natural Resources Finland, (2016).

16. 16 P. Rucinski, USDA Foreign Agric. Serv. (2016).

17. 17 Statistics Estonia: Waste Utilizaton for Elecetrcity and Heat Generation, (2015).

18. 18 International Energy Agency, (2014).

19. 19 Administration of Leningrad region for waste organization and management activities, (2016).

20. 20 LLC SINAI company for secondary raw materials, (2016).

21. 21 F. LDI an Estonian non-profit organisation, governed by the laws of the Republic of Estonia, (2016).

22. 22 E. Kriegler, J.P. Weyant, G.J. Blanford, V. Krey, L. Clarke, J. Edmonds, A. Fawcett, G. Luderer, K. Riahi, and R. Richels, Clim. Change 123, 353 (2014).

23. 23 G.K. Suresh, G. AVSSKS, V. M, and A. M, in 1st Int. Conf. Adv. Therm. Energy Syst., 12, 53-59 (2013).

24. 24 U. Arena, Waste Manag. 32, 625 (2012). 
25. 25 G. Kodzhaspirov and A. Rudskoi, 25th Anniv. Int. Conf. Metall. Mater. Conf. Proc., 248-254 (2016).

26. 26 E.N. Arakcheev, V.E. Brunman, M. V Brunman, A.N. Volkov, V.A. D’yachenko, A. V Kochetkov, and A.P. Petkova, Russ. Eng. Res. 36, 745 (2016).

27. 27 M.J. Andrianova, K. V Vorobjev, J.A. Lednova, and A.N. Chusov, Appl. Mech. Mater. 587-589, 653 (2014).

28. 28 V. Nezdoiminov, V. Ziatina, V. Rozhkov, and D. Nemova, Procedia Eng., 117(1), 1027-1032 (2015).

29. 29 L. V Zysin, N.L. Koshkin, E.I. Orlov, V. V Sergeev, and L.P. Steshenkov, Therm. Eng. (English Transl. Teploenerg). 49, 14 (2002).

30. 30 N. Politaeva, T. Kuznetsova, Y. Smyatskaya, I. Atamaniuk, and E. Trukhina, Adv. Intell. Syst. Comput. 692, 555 (2018).

31. 31 V. Polzer and K.M. Persson, Int. J. Acad. Res. Bus. Soc. Sci. 5(6), 11-34, (2015).

32. 32 H. Tian, C. Lu, P. Ciais, A.M. Michalak, J.G. Canadell, E. Saikawa, D.N. Huntzinger, K.R. Gurney, S. Sitch, and B. Zhang, Nature 531, 225 (2016).

33. 33 P. Villoria-Sáez, V.W.Y. Tam, M. del Río Merino, C.V. Arrebola, and X. Wang, J. Clean. Prod. 127, 49 (2016).

34. 34 A.U. Zaman, Int . J. Environ. Sci. Tech., 7 (2), 225-234 (2010).

35. 35 R. Vasudevan, F.Z. Siddiqui, S. Agrawal, and M. Emran Khan, Solid and liquid waste management, Waste to Wealth (PHI Learning Private Limited, Dheli, 2016).

36. 36 P.H. Brunner and H. Rechberger, Waste Manag., 37, 3-12 (2014).

37. 37 J. Haukohl and T. Rand, U.Marxen, Municipal solid Waste Incineration (World Bank technical paper No. 462, 2000).

38. 38 UK Department for Environment food \& Rural Affairs, (2013).

39. 39 The Blue Ridge Environmental Defense League, (2009).

40. 40 J. Saari, E. Sermyagina, J. Kaikko, E. Vakkilainen, and V. Sergeev, Energy 113, 574 (2016).

41. 41 V. V Sergeev and A.S. Aleshina, Therm. Eng. 58, 268 (2011).

42. 42 A. Fedyukhin, I. Sultanguzin, A. Gyul'Maliev, and V. Sergeev, Eurasian Chem. J. 19, 245 (2017).

43. 43 M. Zhevlakova, N. Zhilnikova, E. Podgaiskii, D. Indriksone, and M. Gratz, Cent. Transbound. Coop. - St. Petersbg. (2012).

44. 44 F. Bazdidi Tehrani and E. Haghi, First Sustain. Dev. Conf. Eng. Syst. Energy, Water Environ. (2015).

45. 45 T.O. of the C. for S.P. Administration of St. Petersburg, (2016).

46. 46 B. Johnke, Emissions from waste incineration, Good Practice Guidance and Uncertainty Management in National Greenhouse Gas Inventories (2001). 